\title{
Perbandingan Suplementasi Tepung Kunyit dan Campuran Tepung Kunyit plus Ekstrak Daun Katuk Fermentasi terhadap Performa, Mutu Karkas dan Komposisi Gizi Daging pada Broiler
}

\author{
Comparison of Supplementation of Turmeric Flour and Turmeric Flour Mixture plus \\ Fermentated Katuk Leaf Extract on Performance, Carcass Quality and Nutritional \\ Composition of Meat in Broilers
}

\section{U. Santoso}

\author{
Jurusan Peternakan, Fakultas Pertanian, Universitas Bengkulu \\ Jalan Raya WR Supratman, Kandang Limun, Bengkulu \\ Corresponding e-mail : uripsantoso60@,gmail.com
}

\begin{abstract}
This study aims to compare two feed additive formulas on the performance and quality of broiler meat. Forty broiler chickens were distributed into 2 groups. Each treatment group consisted of 4 replications, and each replication consisted of 5 broiler chickens. The 2 treatments were as follows: 1) broiler chickens fed diet contained with $4.5 \mathrm{~g}$ Fermented Sauropus androgynus leaf extract (FSALE) plus $4.5 \mathrm{~g}$ turmeric powder (TP)/kg diet (P1) and; 2) broiler chickens fed diet contained with $9 \mathrm{~g} \mathrm{TP} / \mathrm{kg}$ diet (P2). The results showed that two feed additive formulas had no significant effect on body weight, feed intake, feed conversion ratio, carcass weight, meat bone ratio, cooking loss, meat color, odor, taste and texture, protein, fat, cholesterol, carotene, isoleucine, leucine, lauric acid, miristic acid, palmitic acid, stearic acid, linoleic acid, linolenic acid and eicosapentaenoic acid of meats, but significant affected carcass color, and drip loss and iron content $(\mathrm{P}<0.05)$, aspartic acid, glutamic acid, serine, glycine, histidine, arginine, threonine, alanine, proline, tyrosine, valine, methionine, cystine, phenylalanine and lysine $(\mathrm{P}<0.01)$, oleic acid and docosahexaenoic acid of meats $(\mathrm{P}<0.05)$. It can be concluded that formula 1 (mixed FSALE + TP) produced meat with lower drip loss, better iron content, better amino acid composition and lower levels of saturated fatty acids.
\end{abstract}

Ke ywords: Turmeric powder, Sauropus androgynus leaf extract, performance, meat composition.

\begin{abstract}
ABSTRAK
Penelitian ini bertujuan untuk membandingkan dua formula feed additive terhadap performa dan kualitas daging broiler. Empat puluh ekor ayam broiler kemudian didistribusikan ke dalam 2 kelompok. Setiap kelompok perlakuan terdiri dari 4 ulangan, dan masing-masing ulangan terdiri dari 5 ekor ayam broiler. 2 perlakuan tersebut adalah sebagai berikut: 1) ayam broiler diberi pakan ditambah 4,5 g EDKF plus 4,5 g tepung kunyit (TK)/kg pakan (P1) dan; 2) ayam broiler diberi pakan ditambah $9 \mathrm{~g} \mathrm{TK} / \mathrm{kg}$ pakan (P2). Hasil penelitian menunjukkan bahwa dua formula feed additive berpengaruh tidak nyata terhadap berat badan, konsumsi pakan, konversi pakan, berat karkas, meat bone ratio, cooking loss, warna daging, bau, rasa dan tekstur daging, protein, lemak, kolesterol, karotin, isoleucine, leucine, lauric acid, miristic acid, palmitic acid, stearic acid, linoleic acid, linolenic acid dan eicosapentaenoic acid, tetapi berpengaruh nyata terhadap warna karkas, drip loss, kadar besi $(\mathrm{P}<0,05)$, aspartic acid, glutamic acid, serine, glycine, histidine, arginine, threonine, alanine, proline, tyrosine, valine, methionine, cystine, phenylalanine dan lysine $(\mathrm{P}<0,01)$, oleic acid dan docosahexaenoic acid $(\mathrm{P}<0,05)$. Dapat disimpulkan bahwa formula 1 (campuran EDK + TK) menghasilkan daging dengan drip loss yang lebih rendah, kadar besi yang lebih baik, komposisi asam amino yang lebih baik dan kadar asam lemak jenuh yang lebih rendah.
\end{abstract}

Kata kunci: Tepung kunyit, ekstrak daun katuk, performa, komposisi daging.

\section{PENDAHULUAN}

Feed additive komersial mengandung antibiotika yang sudah dilarang penggunaannya di Indonesia. Alasan pelarangan penggunaan antibiotika dalam pakan sebagai pemacu pettumbuhan dikarenakan antibiotika dapat menyebabkan resistensi mikrobia patogen terhadap obat. Hal ini akan menyebabkan semakin lamanya pengobatan terhadap suatu penyakit dan bahkan harus menggunakan dosis yang lebih 
tinggi untuk dapat menyembuhkan penyakit. Selain itu, residu antibiotika yang terakumulasi dalam produk ternak dapat menyebabkan beberapa gangguan antara lain alergi.

Beberapa tumbuhan obat telah diteliti untuk menggantikan antibiotika dalam pakan broiler, antara daun katuk (Santoso, 2001a,b; Santoso et al., 2018), dan tepung kunyit (Nouzarian et al., 2011; Santoso et al., 2015b). Daun katuk kaya akan senyawa antibakteri dan antioksidan seperti fenol, flavonoid, saponin (Santoso, 2014). Serangkaian penelitian menunjukkan bahwa daun katuk mampu menggantikan antibiotika dalam bentuk zinc bacitracin yang terdapat dalam feed additive komersial. Untuk meningkatkan daya guna daun katuk sebagai pengganti antibiotika, maka perlu dikombinasikan dengan bahan alami lainnya seperti kunyit. Kunyit mengandung fenol, flavonoid, alkaloid, terpenoid, tanin dan saponin (Dutta, 2015), yang mempunyai sifat antibakteri dan antioksidan (Kanani et al., 2017).

Penelitian ini bertujuan untuk membandingkan dua formula feed additive, yaitu tepung kunyit, dan campuran tepung kunyit dan ekstrak daun katuk terhadap performa dan mutu karkas ayam broiler.

\section{MATERI DAN METODE}

\section{Ekstraksi daun katuk fermentasi}

Daun katuk difermentasi oleh Saccharomyces cerevisiae (Santoso et al., 2015), dan kemudian diekstraksi dengan air panas pada $90{ }^{\circ} \mathrm{C}$ selama 20 menit seperti yang dijelaskan oleh Santoso et al. (2005).

\section{Pemeliharaan broiler}

Seratus broiler dibeli (Arbor Acres) dari penetasan komersial. Broiler dipelihara sesuai dengan Santoso et al. (2001) dan Santoso et al. (2015a). Pada saat kedatangan, broiler ditempatkan dalam kandang tunggal dikelilingi oleh cincin bambu dan litter dari sekam padi dengan kedalaman sekitar $5 \mathrm{~cm}$. Dari umur 1-14 hari, panas tambahan diberikan dengan menggunakan bahan bakar batubara. Suhu dipertahankan pada $32-340 \mathrm{C}$ pada minggu pertama dan secara bertahap menurun pada minggu kedua. Ayam broiler dipelihara di lantai dalam kandang di bawah pencahayaan terus menerus. Untuk menghindari stres, anak-anak ayam broiler segera diberi air minum yang mengandung gula dan substrat antistress. Mereka diberi makan pakan komersial selama 14 hari. Pada umur 15 hari, broiler ditimbang dan dipilih atas dasar berat badan. Rancangan acak lengkap yang digunakan dalam penelitian ini. Empat puluh ekor ayam broiler kemudian didistribusikan ke dalam 2 kelompok. Setiap kelompok perlakuan terdiri dari 4 ulangan, dan masing-masing ulangan terdiri dari 5 ekor ayam broiler. 2 perlakuan tersebut adalah sebagai berikut:

1) ayam broiler diberi pakan ditambah $4,5 \mathrm{~g}$ EDKF plus 4,5 g tepung kunyit (TK) $/ \mathrm{kg}$ pakan (P1)

2) ayam broiler diberi pakan ditambah $9 \mathrm{~g}$ $\mathrm{TK} / \mathrm{kg}$ pakan (P2)

Pakan penelitian mengandung protein kasar 19\% dan $3200 \mathrm{kkal} \mathrm{ME} \mathrm{/} \mathrm{kg.} \mathrm{Konsumsi}$ pakan, berat badan dan konversi pakan diukur setiap minggu. Semua ayam broiler diberikan diet dan minum ad libitum air.

Tabel 1. Susunan pakan penelitian

\begin{tabular}{lll}
\hline Bahan pakan, \% & P1 & P2 \\
\hline Jagung & 56.80 & 56.80 \\
Dedak & 5.00 & 5.00 \\
Konsentrat broiler & 34.00 & 34.00 \\
Minyak sawit & 1.50 & 1.50 \\
EDKF & 0.45 & 0 \\
Tepung kunyit & 0.45 & 0.90 \\
Mineral mixture & 1.70 & 1.70 \\
Topmix & 0 & 0 \\
Garam & 0.10 & 0.10 \\
Komposisi gizi & & \\
ME, kcal/kg & 3145 & 3145 \\
Protein, \% & 19.06 & 19.06 \\
\hline
\end{tabular}

\section{Sampling}

Pada akhir studi (umur 35 hari), 5 ekor ayam broiler untuk masing-masing kelompok perlakuan dipotong dan bobot karkas, warna karkas, rasio tulang daging, kehilangan memasak, dan kehilangan tetes 
kemudian diukur. warna karkas diukur dengan membandingkan standar warna dari DSM dengan warna kulit dada. Cooking loss diukur setelah memasak daging dada selama 20 menit pada $80 \mathrm{oC}$. Cooking loss dilaporkan sebagai persentase dan dihitung sebagai (berat awal - berat akhir) / (berat awal)

100.

Drip loss dapat didefinisikan sebagai kehilangan berat dari produk makanan karena ekstrusi dan menetes pergi dari jus jaringan, seperti jus daging hilang selama pencairan daging beku. Drip loss diukur setelah pembekuan daging dada selama 72 jam. Drip loss dilaporkan sebagai persentase dan dihitung sebagai (berat awal - berat akhir) / (berat awal) $x$ 100. Rasio daging tulang diukur dengan membandingkan daging dada ditambah daging paha dengan tulang dada dan paha. Karkas adalah bagian dari tubuh ayam pedaging disembelih tanpa bulu, jeroan kecuali paru-paru dan ginjal, betis, leher dan kepala (Santoso \& Sartini, 2001).

Untuk menguji organoleptik, sepuluh panelis sensori yang telah dilatih diminta untuk membandingkan rasa relatif, bau, dan warna daging. Panelis diminta untuk menilai warna, bau dan rasa daging dada dari kelas 1 sampai 5. Warna daging dinilai dengan membandingkan warna daging dada dengan skala referensi warna ID-DLO standar 1-5. Bau itu dinilai berdasarkan nilai 1 (sangat amis), nilai 2 (amis), nilai 3 (sedikit amis), nilai 4 (kurang amis) dan nilai 5 (tidak amis). Untuk uji rasa, panelis sebelumnya dilatih dengan cara mencicipi dada ayam kaldu yang diperoleh dengan merebus daging pada berbagai konsentrasi. Nilai 1 (rasa tidak enak) diperoleh dengan membuat kaldu daging $1 \mathrm{~g}$ direbus dalam $50 \mathrm{ml}$ air; nilai 2 (rasa kurang enak) pada rasio $4 \mathrm{~g}$ daging / 50 $\mathrm{ml}$ air; 3 nilai (rasa cukup enak) pada rasio 7 $\mathrm{g}$ daging / $50 \mathrm{ml}$ air; nilai 4 (enak) pada rasio $10 \mathrm{~g}$ daging / $50 \mathrm{ml}$ air; dan skor 5 (sangat enak) dengan rasio $13 \mathrm{~g}$ daging / $50 \mathrm{ml}$ air. Setelah panelis bisa membedakan rasa daging seperti yang diharapkan, mereka kemudian diminta untuk mencicipi dan menilai rasa daging yang tidak enak (nilai 1) ke sangat enak (skor 5). Untuk rasa dan bau tes, daging yang dikukus pada $80^{\circ} \mathrm{C}$ selama 20 menit, didinginkan dan kemudian menguji rasa dan bau.

Daging kaki untuk setiap perlakuan dikoleksi untuk analisis kolesterol, protein, lemak, asam lemak, besi, karotin dan asam amino. Hasil penelitian dianalisis $t$ test.

\section{HASIL DAN PEMBAHASAN}

Tabel 2 menunjukkan perbandingan dua formula feed additive terhadap performa ayam broiler. Hasil uji $\mathrm{t}$ menunjukkan bahwa perbedaaan formula feed additive berpengaruh tidak nyata terhadap berat badan, pertambahan berat badan, konsumsi dan konversi pakan. Hal ini menunjukkan kedua formula yang diteliti sama efektifnya sebagai feed additive dalam menghasilkan performa broiler.

Tabel 2. Perbandingan suplementasi tepung kunyit dengan campuran tepung kunyit plus ekstrak daun katuk fermentasi terhadap performa ayam broiler.

\begin{tabular}{lll}
\hline Variabel & P1 & P2 \\
\hline Berat, g & $1745 \pm 127$ & $1723 \pm 146$ \\
PBB, g/ekor & $1292 \pm 122$ & $1261 \pm 63$ \\
Konsumsi, g/ekor & $2678 \pm 154$ & $2640 \pm 201$ \\
FCR & $2,08 \pm 0,13$ & $2,09 \pm 0,13$ \\
\hline P1= & Broiler diberi pakan yang mengandung tepung \\
& kunyit plus ekstrak daun katuk fermentasi; \\
$\mathrm{P} 2=$ & $\begin{array}{l}\text { Broiler diberi pakan yang mengandung tepung } \\
\text { kunyit. }\end{array}$
\end{tabular}

Tabel 3 menyajikan perbandingan dua formula feed additive terhadap kualitas kaskas ayam broiler. Hasil uji t menunjukkan bahwa perlakuan berpengaeruh tidak nyata $(\mathrm{P}>0,05)$ terhadap berat karkas, meat bone ratio, cooking loss, warna daging, bau, rasa dan tekstur daging, tetapi berpengaruh nyata terhadap warna karkas dan drip loss $(\mathrm{P}<0,05)$. $\quad \mathrm{P} 1$ lebih kuning dari pada $\mathrm{P} 2$ $(\mathrm{P}<0,05)$, sementara $\mathrm{P} 2$ mempunyai drip loss yang lebih rendah daripada $\mathrm{P} 1(\mathrm{P}<0,05)$. 
Tabel 3. Perbandingan suplementasi tepung kunyit dengan campuran tepung kunyit plus ekstrak daun katuk fermentasi terhadap mutu karkas ayam broiler

\begin{tabular}{lll}
\hline Variabel & $\mathrm{P} 1$ & $\mathrm{P} 2$ \\
\hline Berat karkas, \% & $68,6 \pm 1,06$ & $70,0 \pm 1,47$ \\
Meat bone ratio & $5,23 \pm 0,53$ & $5,09 \pm 0,91$ \\
Warna karkas & $104 \pm 0,54^{\mathrm{b}}$ & $103,4 \pm 0,6^{\mathrm{a}^{*}}$ \\
Cooking loss & $29,19 \pm 6,69$ & $22,78 \pm 5,89$ \\
Drip loss & $6,19 \pm 2,89^{\mathrm{b}}$ & $5,26 \pm 2,26^{\mathrm{a}^{*}}$ \\
Warna daging & $3,25 \pm 0,29$ & $3,38 \pm 0,25$ \\
Rasa & $4,0 \pm 0,2$ & $3,9 \pm 0,2$ \\
Bau & $3,8 \pm 0,2$ & $4,2 \pm 0,1$ \\
Tekstur & $3,0 \pm 0,2$ & $3,4 \pm 0,1$ \\
\hline
\end{tabular}

$\mathrm{P} 1=$ Broiler diberi pakan yang mengandung tepung kunyit plus ekstrak daun katuk fermentasi;

$\mathrm{P} 2=$ Broiler diberi pakan yang mengandung tepung kunyit.

Lebih kuningnya warna karkas pada P1 disebabkan oleh $\beta$-karotin yang terdapat dalam ekstrak daun katuk. Santoso et al. (2017) melaporkan bahwa ekstrak daun katuk mengandung $\beta$-karotene sebesar 3,642.6 $\mu \mathrm{g}$ $\beta$-carotene $/ \mathrm{g}$.

Wang et al. (2015) melaporkan bahwa pemberian ekstrak kunyit menurunkan drip loss pada ayam broiler. Drip loss merupakan variabel yang menunjukkan banyaknya cairan yang keluar dari daging setelah daging dithawing. Semakin tinggi nilai drip loss maka akan semakin tinggi cairanya yang hilang dari daging sehingga akan mengurangi mutu daging (Otto et al., 2004). Hasil penelitian Wang et al. (2015) menunjukkan bahwa ekstrak kunyit meningkatkan kemampuan antioksidan dalam broiler, sehingga menjaga integritas membran sel dan menurunkan drip loss (Wang et al., 2015)

Tabel 4 menyajikan perbandingan dua formula terhadap komposisi gizi daging broiler. Hasil uji t menunjukkan bahwa perlakuan berpengaruh tidak nyata terhadap protein, lemak, kolesterol, karotin, tetapi berpengaruh nyata terhadap kadar besi daging $) \mathrm{P}<0,05)$. $\mathrm{P} 1$ mempunyai kadar besi lebih tinggi daripada P2 $\quad(\mathrm{P}<0,05)$. Santoso et al. (2017) melaporkan bahwa suplementasi ekstrak daun katuk meningkatkan kadar besi daging broiler. Daun katuk kaya akan zat besi (Santoso et al., 2015a). Zat besi merupakan senyawa mineral yang berperan penting dalam sintesis mioglobin, suatu pigmen warna daging.

Tabel 4. Perbandingan suplementasi tepung kunyit dengan campuran tepung kunyit plus ekstrak daun katuk fermentasi terhadap komposisi gizi daging broiler

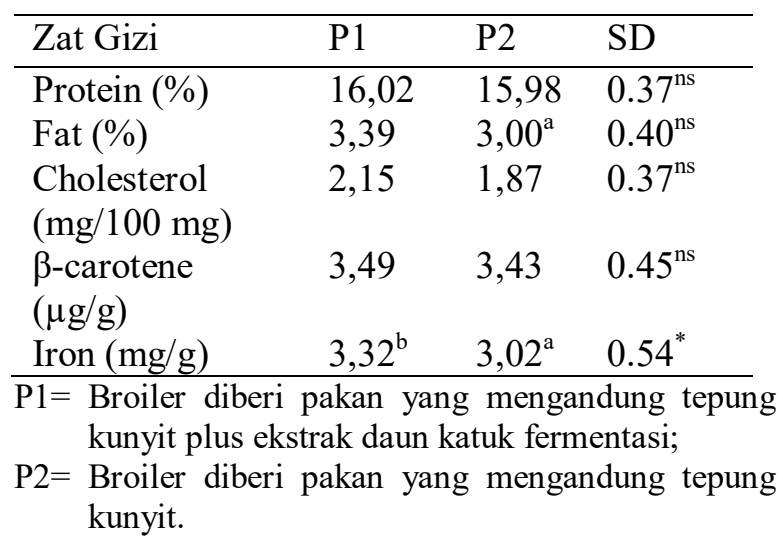

Tabel 5. Perbandingan suplementasi tepung kunyit dengan campuran tepung kunyit plus ekstrak daun katuk fermentasi terhadap komposisi asam amino daging broiler

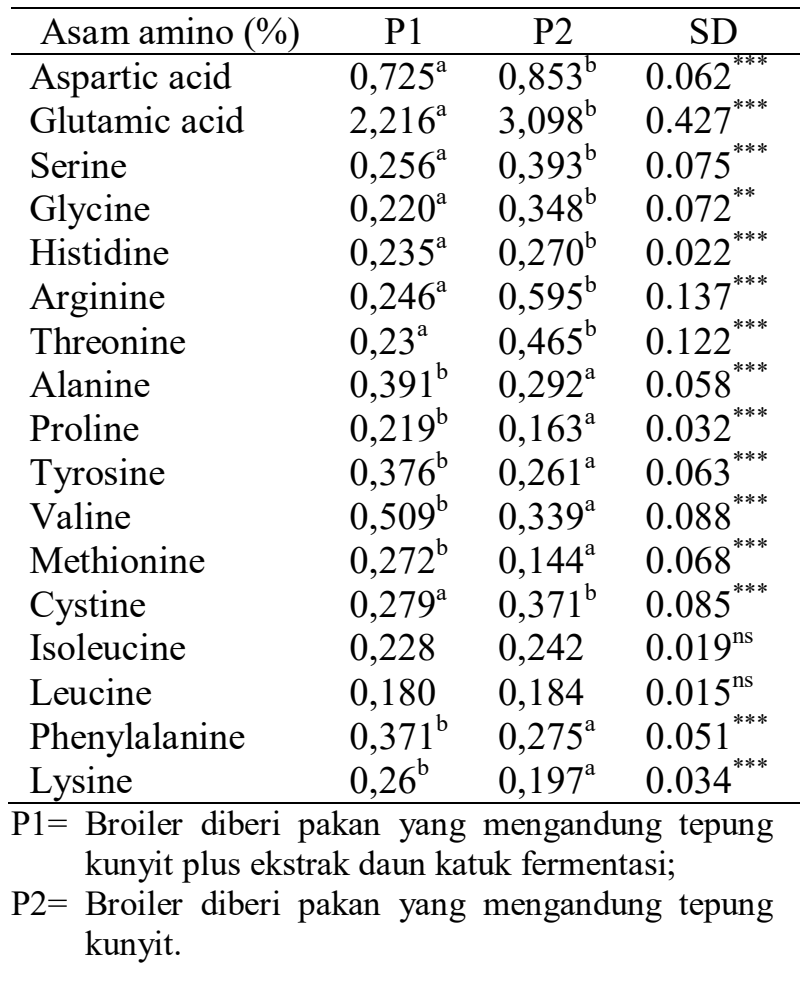


Tabel 5 menyajikan pegaruh formula feed additive terhadap komposisi asam amino daging. Hasil uji $\mathrm{t}$ menunjukkan bahwa perlakuan berpengaruh sangat nyata terhadap aspartic acid, glutamic acid, serine, glycine, histidine, arginine, threonine, alanine, proline, tyrosine, valine, methionine, cystine, phenylalanine dan lysine $(\mathrm{P}<0,01)$, tetapi berpengaruh tidak nyata terhadap isoleucine dan leucine $(\mathrm{P}>0,05)$. P1 mempunyai kadar aspartic acid, glutamic acid, serine, glycine, histidine, arginine, threonine, cystine yang lebih rendah daripada $\mathrm{P} 2(\mathrm{P}<0,01)$, tetapi $\mathrm{P} 1$ mempunyai kadar alanine, proline, tyrosine, valine, methionine, phenylalanine dan lysine yang lebih tinggi daripada $\mathrm{P} 2 \quad(\mathrm{P}<0,01)$. Perbedaan komposisi asam amino pada $\mathrm{P} 1$ dan P2 diduga disebabkan oleh perbedaan komposisi asam amino yang dikandung oleh formula tersebut. Ekstrak daun katuk mengandung asam aspartat $0,754 \%$, asam glutamat 2,221\%, serin 0,258\%, glisin $0,216 \%$, histidine $0,243 \%$, arginin $0,258 \%$, treonin $0,221 \%$, alanin $0,408 \%$, prolin $0,227 \%$, tirosin $0,393 \%$, valin $0,523 \%$, metionin $0,281 \%$, sistin $0,226 \%$, isoleusin $0,245 \%$, leusin $0,185 \%$, fenilalanin $0,36 \%$ dan lisin 0,275\% (Santoso et al., 2017). Sharma et al. (2013) melaporkan bahwa kunyit mengandung leusin 7,36 mg/100 g kunyit, valin 3,21 , lisin 1,58, treonin 1,32, fenilalanin 1,94, isoleusin 1,12, metionin 0,32 , histidin 2,24 , alanin 2,86 , arginin 0,84 , asam aspartat 14,34, sistin nd, asam glutamat 8,32 , glisin 1,32 , prolin 0,78 , serin 2,86 dan tirosin 3,21 .

Tabel 6 menyajikan perbandingan dua formula feed additive terhadap komposisi asam lemak daging broiler. Perlakuan berpengaruh tidak nyata terhadap lauric acid, miristice acid, palmitic acid, stearic acid, linoleic acid, linolenic acid dan eicosapentaenoic acid $(\mathrm{P}>0,05)$, tetapi berpemgaruh nyata terhadap oleic acid dan docosahexaenoic acid $(\mathrm{P}<0,05)$. P1 mempunyai kadar oleic acid lebih tinggi daripada P2 $(\mathrm{P}<0,05)$, tetapi mempunyai kadar docohexaenoic acid yang lebih rendah $(\mathrm{P}<0,05)$. Asam lemak jenuh pada $\mathrm{P} 1$ adalah sebesar 16,885g/100 g lemak, sementara pada P2 sebesar 12,302 g/100 g lemak. Ini menunjukkan bahwa broiler yang diberi pakan mengandung 0,9\% tepung kunyit mempunyai asam lemak jenuh yang lebih rendah. Daneshyar et al. (2011) melaporkan bahwa pemberian tepung kunyit tidak menurunkan asam oleat, tetapi menurunkan asam lemak jenuh.

Tabel 6. Perbandingan suplementasi tepung kunyit dengan campuran tepung kunyit plus ekstrak daun katuk fermentasi terhadap komposisi asam lemak daging broiler

\begin{tabular}{llll}
\hline Asam lemak (g/100g lemak) & P1 & P2 & SD \\
\hline Lauric acid & 0,009 & 0 & $0.009^{\text {ns }}$ \\
Miristic acid & 0,009 & 0,082 & $0.205^{\text {ns }}$ \\
Palmitic acid & 2,370 & 1,997 & $0.440^{\text {ns }}$ \\
Stearic acid & 14,497 & 10,223 & $3.659^{\text {ns }}$ \\
Oleic acid & $43,562^{\mathrm{b}}$ & $30,992^{\mathrm{a}}$ & $8.897^{*}$ \\
Linoleic acid & 10,288 & 9,959 & $3.514^{\mathrm{ns}}$ \\
Linolenic acid & 0,415 & 0,337 & $0.142^{\mathrm{ns}}$ \\
$\begin{array}{l}\text { Docosahexaenoic acid } \\
\text { (mg/100 g fat) }\end{array}$ & $4,531^{\mathrm{a}}$ & $6,347^{\mathrm{b}}$ & $0.466^{* * *}$ \\
$\begin{array}{l}\text { Eicosapentaenoic acid } \\
\text { (mg/100 g fat) }\end{array}$ & 2,939 & 3,920 & $1.049^{\mathrm{ns}}$ \\
\hline
\end{tabular}

P1= Broiler diberi pakan yang mengandung tepung kunyit plus ekstrak daun katuk fermentasi;

$\mathrm{P} 2=$ Broiler diberi pakan yang mengandung tepung kunyit. 


\section{KESIMPULAN}

Dapat disimpulkan bahwa herbal formula $2 \quad(0,9 \%$ tepung kunyit $)$ menghasilkan daging dengan drip loss dan kadar besi dan asam lemak jenuh daging yang lebih rendah, dan kadar asam lemak jenuh yang lebih rendah. Sementara herbal formula 1 (daun katuk plus kunyit) menghasilkan daging dengan kadar besi lebih tinggi dan komposisi asam amino yang lebih baik.

\section{DAFTAR PUSTAKA}

Daneshyar, M., M. A. Ghandkanlo, F. S, Bayeghra, F. Farhangpajhoh dan M. Aghaei. 2011. Effects of dietary turmeric supplementation on plasma lipoproteins,meat quality and fatty acid composition in broilers. S. Afr. J. Anim. Sci. vol. 41: 42-48.

Dutta, B. 2015. Study of secondary metabolite constituents and curcumin contents of six different species of genus Curcuma. JMPS 2015; 3(5): 116119.

Kanani, P. B., M. Daneshar, J. Aliakbarlu dan F. Hamian. 2017. Effect of dietary turmeric and cinnamon powders on meat quality and lipid peroxidation of broiler chicken under heat stress condition. Veterinary Research Forum. 2017; 8 (2):163 - 169 .

Nouzarian, R., S.A. Tabeidian, M. Toghyani, G. Ghalamkari and M. Toghyani. 2011. Effect of turmeric powder on performance, carcass traits, humoral immune responses, and serum metabolites in broiler chickens. J. Anim. Feed Sci., 2: 389-400.

Otto, G., R. Roehe, H. Looft, L. Thoelking, and E. Kalm, 2004. Comparison of different methods for determination of drip loss and their relationships to meat quality and carcass characteristics in pigs. Meat Sci. 68:401-409.
Santoso, U. 2001a. Effect of Sauropus androgynus extract on the performance of broiler. Buletin Peternakan dan Perikanan, 7: 15-21.

Santoso, U. 2001b. Effect of Sauropus androgynus extract on the carcass quality of broiler chicks. Buletin Peternakan dan Perikanan, 7: 22-28.

Santoso, U. 2014. Tumbuhan Multi Khasiat. Badan Penerbitan Fakultas Pertanian (BPFP), Universitas Bengkulu.

Santoso, U. and Sartini. 2001. Reduction of fat accumulation in broiler chickens by Sauropus androgynus (Katuk) leaf meal supplementation. Asian-Aust. J. Anim. Sci. 14:346-350.

Santoso, U., Suharyanto and E. Handayani. 2001. Effects of Sauropus androgynus (Katuk) leaf extract on growth, fat accumulation and fecal microorganisms in broiler chickens. Jurnal Ilmu Ternak dan Veteriner, 6: 220-226.

Santoso, U., J. Setianto and T. Suteky. 2005. Effect of Sauropus androgynus (katuk) extract on egg production and lipid metabolism in layers. Asian-Aust. J. Anim. Sci. 18:364-369.

Santoso, U., Y. Fenita, Kususiyah and I. G. N. G. Bidura. 2015a. Effect of fermented Sauropus androgynus leaves on meat composition, amino acid and fatty acid compositions in broiler chickens. Pak. J. Nutr. 14:799-807.

Santoso, U., Kususiyah and Y. Fenita. 2015b. The effect of Sauropus androgynus leaves extract plus turmeric powder on fat deposition, carcass quality and blood profile in broilers fed low protein diets. J. Indonesian Trop. Anim. Agric. 40: 121-130.

Santoso, U., Y. Fenita dan Kususiyah. 2017. Effect of fermented Sauropus androgynus leaf extract on the chemical composition of broiler meat. Pak. J. Nutr., 16: 306-313. 
Santoso, U., Y. Fenita, Kususiyah, O. Widiantoro and S. Kadarsih. 2018. The effect of medicinal herb on fat deposition, meat composition, amino acid and fatty acid composition of broiler meats. J. Indonesian Trop. Anim. Agric., 43(1):54-65.

Sharma, D. Kr., A. Maheshwari dan P. M. Gupta. 2013. Nutritional analysis of Curcuma longa L. in different cities of west uttar Pradesh (INDIA). Int. J. Chem. Pharmaceutical Sci. 4 (4): 7-14.

Wang, D., H. Huang, L. Zhou, W. Li, H. Zhou, G. Hou, J. Liu dan L. Hu. 2015. Effects of dietary supplementation with turmeric rhizome extract on growth performance, carcass characteristics, antioxidant capability, and meat quality of wenchang broiler chickens. Ital. J. Anim. Sci., 14: 343-349. 